\title{
Analysis Technology and Cathodic Protection for Hull Structures of Ships and Floating Facilities
}

\author{
$\operatorname{Vadim}_{\text {Kramar }}{ }^{1}\left(\mathbb{D}\right.$, Anna Rodkina ${ }^{1}\left(\mathbb{D}\right.$, Olga Ivanova $^{1,2}$, Sergei Chernyi ${ }^{3,4,5, * \mathbb{C}}$ and Anton Zinchenko ${ }^{5}$ \\ 1 Department of Innovative Shipbuilding and Shelf Development Technologies, Federal State Educational \\ Institution of Higher Education "Sevastopol State University", 299053 Sevastopol, Russia; \\ kramarv@mail.ru (V.K.); a.v.rodkina@gmail.com (A.R.); o.a.ivanova.kmt@mail.ru (O.I.) \\ 2 Central Design Bureau "Corall" JSC, 299028 Sevastopol, Russia \\ 3 Department of Integrated Information Security, Admiral Makarov State University of Maritime and Inland \\ Shipping, 198035 Saint-Petersburg, Russia \\ 4 Department of Ship's Electrical Equipment and Automatization, Kerch State Maritime Technological \\ University, 298309 Kerch, Russia \\ 5 Department of Cyber-Physical Systems, Saint Petersburg State Marine Technical University, Leninskiy Prosp., \\ 101, 198303 Saint-Petersburg, Russia; Antel85@bk.ru \\ * Correspondence: chernysg@gumrf.ru
}

Citation: Kramar, V.; Rodkina, A.; Ivanova, O.; Chernyi, S.; Zinchenko, A. Analysis Technology and Cathodic Protection for Hull Structures of Ships and Floating Facilities. Inventions 2021, 6, 74. https://doi.org/ 10.3390 /inventions6040074

Academic Editor: Richard

G. Compton

Received: 25 August 2021

Accepted: 25 October 2021

Published: 28 October 2021

Publisher's Note: MDPI stays neutral with regard to jurisdictional claims in published maps and institutional affiliations.

Copyright: (c) 2021 by the authors. Licensee MDPI, Basel, Switzerland. This article is an open access article distributed under the terms and conditions of the Creative Commons Attribution (CC BY) license (https:// creativecommons.org/licenses/by/ $4.0 /)$.

\begin{abstract}
Studies overviewed in the paper have yielded a number of new scientific results including the following: suggested is a technique for conducting experimental investigations of electrochemical characteristics of hull structures of ships and floating facilities on the juvenile surface under cathodic polarization in a test seawater solution with the use of the test facility developed for investigating electrochemical characteristics of hull structures of ships and floating facilities on the juvenile surface under cathodic polarization; obtained are the results of laboratory experiments on various shipbuilding steels without surface oxide films in test seawater solutions with a widely ranging salinity spectrum; developed is a neural network-based technique for predicting the protection potential of ships and floating facilities from local corrosion mechanical damages; developed is an algorithm for obtaining the protective potential for hull structures of ships and floating facilities; suggested is a method of protecting hull structures of ships and floating facilities by means of cathodic polarization from local corrosion mechanical damages at the potential of the uncharged surface on the juvenile surface of steel; revealed are beneficial effects of using cathodic polarization by impressed current at the potential of the uncharged surface on the juvenile surface of steel which allow the prolongation of the service life of hull structures of ships and floating facilities.
\end{abstract}

Keywords: hull structures of ships and floating facilities; local corrosion mechanical damage; protective potential; cathodic protection; neural network-based prediction; ship's weight load

\section{Introduction}

In operating conditions, the ship hull is exposed to a number of loads and other factors such as loads due to cargo being shipped; loads due to waves and wind, in case of navigation in storm conditions; hydrodynamic forces due to wave impacts (slamming, whipping); loads due to machinery vibrations and cargo shifts; loads due to increase in ship sizes; and permanent influence of aggressive environment. Each type of load results in damages that can either be relatively harmless or lead to severe consequences. Damages occur not just due to exposure to actions not accounted for in determining scantlings, but also due to defects (i.e., structural and engineering deficiencies in arrangement of hull structural assemblies with an excessive stress concentration; inadequate quality of material) introduced at design and construction phases and due to continuous corrosion processes during the entire service life of the ship as well [1]. In most cases, the occurrence of hull damage and shipwreck result from the confluence of the above factors and circumstances. Identifying the causes of damage to hull structures is a challenge. The principal cause (i.e., 
forces due to ship's overall bending) of severe damages can be identified. Overall bending poses the main danger to the hull primarily because of the threat of hull break (Figure 1). In turn, corrosion processes have an additional negative influence on the rate of metal failure in stressed areas [2], as confirmed by losses of the container ship MOL Comfort [1,3-5]; the Japanese ore carrier California Maru [6-8]; 20 ships which signaled their distress on 10-11 November 2007, in the Kerch Strait [9]; the oil production platform Alexander Keilland [10]; and the Deepwater Horizon oil platform [11].

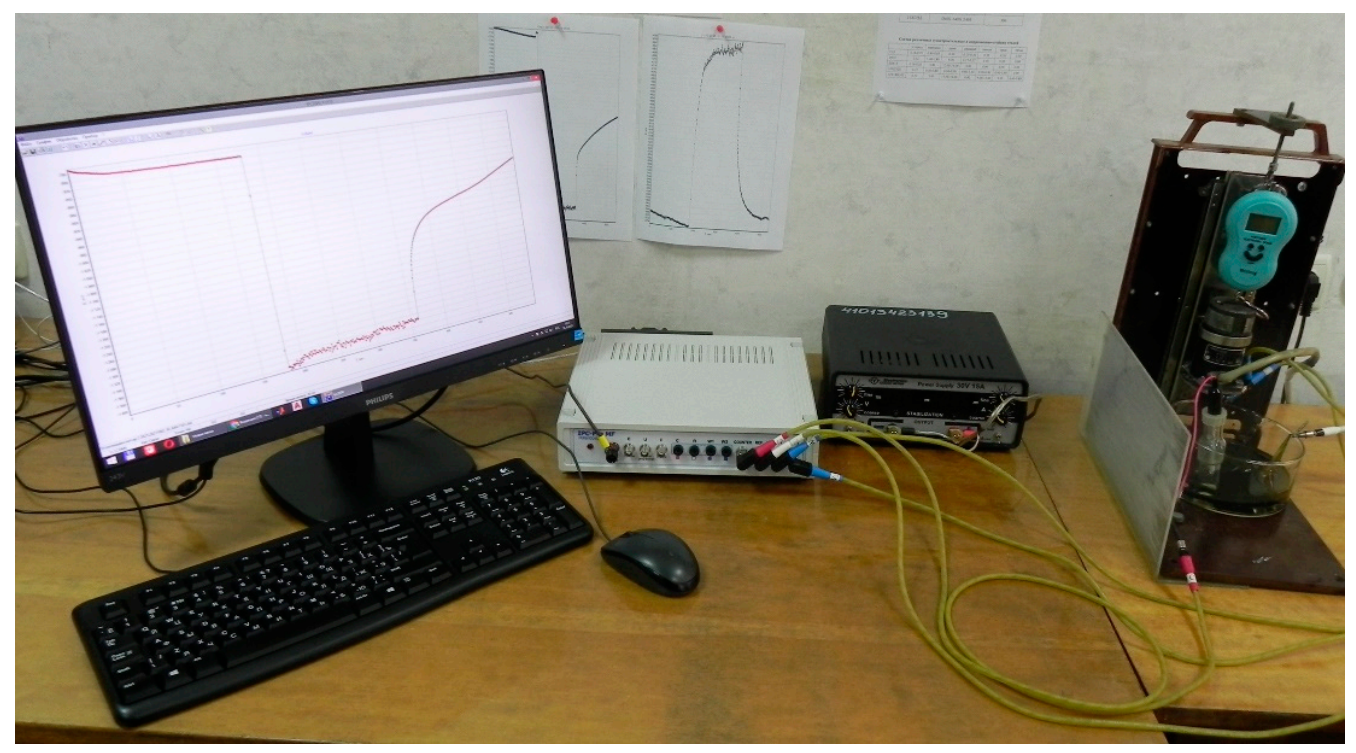

Figure 1. Test facility.

As an example of a shipwreck with the hull hogged under stormy conditions, one can analyze the serviceability and stressed state of the hull of the dry-cargo ship Haj Ismail, which had an accident and sank off the Cape Chersonese (Sevastopol) on 7 November 2007. The strength and reliability of the hull depend primarily on corrosion wear of the outer shell and bottom/side framing and the deck and inner bottom plating induced by general corrosion. For the ship in question, the reduction in hull shell plating thickness associated with that wear after a 26-27-year operation period was 1.7 to $2.2 \mathrm{~mm}$ (17 to $24 \%$ ) according to [6] and can be taken for the estimation of general corrosion of dry-cargo ships, since measured data on plating thickness during the last docking of the ship are usually unavailable. The calculated wear of the plating and hull framing indicates a reduction in hull stiffness (moment of inertia of a cross-section) and strength (modulus of resistance of the deck and bottom).

It should be noted that the butt-welded joints of the shell and framing are subject to the greatest corrosion wear. That results in an increase in the effective stress concentration factor [7], which characterizes the reduction of fatigue strength under alternating load.

\section{Materials and Methods}

About $40 \%$ of offshore accidents result from failures of a unit's substructures or legs [12]. Damages occur because of stresses in the legs, which contribute to the cracking of leg material (metal). Seawater salinity ranges worldwide from 7 to $35 \%$. The presence of inorganic salts, especially chlorides, in seawater increases water conductivity and adsorption activity and thus intensifies the process of electrochemical corrosion. The main reason why seawater is corrosively active towards most structural materials is the presence of chlorine ions in seawater, which accelerates the development of local defects (cracks, etc.), i.e., provokes corrosion cracking.

Corrosion is the most important problem for shipbuilding. The acuteness of this problem increases because the growth rate of corrosion losses exceeds the growth rate of 
metal production. Notably, metal loss is not governing. Generally, any other expenditures associated with failures of skids and metal structures are not considered. The actual economic damage due to the loss of an offshore structure includes contributions from the following factors: the cost of lost equipment, the cost of repair and restoration, losses related to downtime, etc.

Studies by domestic and foreign scientists into the problems of corrosion of metals and methods of protection of sea-going vessels and ocean engineering facilities against various-type corrosive damages have been underway starting from the 1950s. The issues of steel strength in a corrosive environment were investigated by Karpenko G.V. [13-15] and Ryabchenkov A.V. [16], while the fatigue and crack resistance of structural materials were studied by Ozhiganov Yu G. [17] and Yarema S.Ya. [18,19]. Some methods of corrosion tests were suggested by Zimina T.Yu., Rakoch A.G., Panov M.K., Oshe E.K. and Fokin M.N. [20]; the investigation of the polarization effect on corrosion cracking and stresscorrosion strength of steels was described by Kuzmin Y.L., Laschevskii V.O. and Kalinin G.Y. [21]; and the surface-active medium effect on the deformation processes of metals was presented by Rebinder P.A., Shchukin E.D., and Karpenko G.V. [15,22]. Investigations dedicated to the methods of protection against corrosion damage were performed by von Baeckmann W., Schwenk W. and Prinz W. [23]; Morley J., Chandler K.A. and O'Brien J.E. [24]; Gorynin I.V. and Kuzmin Y.L. [25]; and Mujezinović A., Kim J.-H., Mainier F.B., Xing S.H. and Han E. [26-30]. Neural network modeling and analysis were performed in the longevity assessments by Zelentsov D.G. [31,32]; neural network control of impressedcurrent cathodic corrosion protection was studied by Kadhim Hussein [33].

The purpose of the study is to increase the durability of hull structures of ships and floating facilities by improving the efficiency of determining the parameters of protection against local corrosion mechanical damage at the design stage.

As evidenced from many years of operation, when exposed to seawater, the steel hull structures of ships and floating facilities suffer intense corrosion damages which become stress concentrators and under certain conditions can lead to steelwork failure due to lower corrosion fatigue strength. The loss of serviceability of ship structures stemming from deterioration by corrosion depends largely on the type of actual corrosion damage. Ship structures exposed to seawater can suffer any of the known types of corrosion damage.

Both uniform and nonuniform types of corrosion reduce structural strength solely due to a reduction in cross-section of structural members. Localized corrosion mechanical damages are the most dangerous types. Localized corrosion covers discrete sites on the metal surface [34].

The world statistics on ship accidents [35] indicate that brittle failure is the most dangerous type of failure for engineering facilities. These failures are initiated abruptly and spread at a high speed. The causes of the brittle failures are defects such as cracks; corrosion-fatigue cracks, which are likely to occur in the weld areas during the operation of the ship; and design and engineering defects of various origin: in the areas of stress concentrators in locations of sharp changes in the cross-section of members, in way of intersection of different elements of framing, in cutouts, and in structural members.

Protective measures for hull structures of ships and floating facilities are determined at the design stage. Various methods of protection against corrosion damages have been identified in course of the review of scientific literature. One of the most efficient active methods of preventing corrosion of offshore facilities is the electrochemical protection based on cathodic polarization of metal by the use of current. A distinction is made between electrochemical protection by means of protectors (sacrificial anodes) and cathodic protection by impressed current.

At the design stage, in order to provide means to prevent and control the deterioration of hull structures of ships and floating facilities, it is necessary to study in more detail the physical aspects of the processes of interaction between the seawater and the hull structures. The protector is a metal with a higher negative potential that, upon coming in contact with the ship's hull, becomes an anode and thereafter gives up positively charged ions to 
the seawater while dissolving in it. Excess electrons flow into the metal of the ship's hull, whose underwater structures represent the cathode and are not destroyed in the process. In cathodic protection, the ship's hull is connected to the negative terminal of the DC source, while the anode is connected to its positive terminal. Cathodic polarization of the ship's hull surface is performed, with the potential shifting in the negative direction. The comparative analysis shows that the method of cathodic protection with impressed current has more advantages. Parameters of cathodic protection against corrosion are described in numerous guidance materials and research papers [36-39]. However, as the practice shows, those parameters do not provide adequate protection, especially in the presence of local corrosion mechanical damages; i.e., there is either insufficient protection against corrosion or excessive protection which provokes corrosion cracking and other types of local damages.

If the metal develops local corrosion damage in the form of narrow indentations, tensile stresses perpendicular to the direction of those indentations will facilitate the occurrence of stress concentrations at their apexes. As a result, the crack apex will reveal a fresh, unprotected by oxide film, juvenile surface (JS), which, as being more anodic, is exposed to an intense corrosive environment that tends to accelerate corrosion. Thus, the existing methods of corrosion protection change the course of the corrosion process; however, the presence of local defects on the steel surface hampers the achievement of effective protection due to the incapability of determining the stationary potential value of the juvenile surface of the metal.

\subsection{Algorithm and Structure of the Experiment}

The determination of the potential of the metal surface without an oxide film is one of the main factors necessary to prevent the development of local damages. In this case, traditional research methods tend to yield unrealistic results for a number of reasons [40]. In the furtherance of this goal, a test facility was developed to investigate the electrochemical characteristics of hull structures of ships and floating facilities on the juvenile surface under cathodic polarization (Figure 1). The unique feature of the test facility is its capability of determining metal potential at the apex of the local damage, i.e., on the JS. The operation principle is based on the rotation of the grinding disk against the surface of the working sample under various pressures at various speeds. The rotation of the element is initiated by switching the motor on.

For the experimental investigations, the authors [40] used samples of shipbuilding steels of categories A, B, D, BW, DW, EW, FW, D40S, A40S, and E40S and corrosion-resistant steel grades 20Ch13 and 12Ch18N10T (Samples of Russian production. Approved by the standards of the Russian Federation and recognized in the World.). The area of the working surface of the sample did not exceed $500 \mathrm{~mm}$. Metal potential was measured relative to the silver chloride reference electrode using a voltmeter. Test seawater solutions varying in salinity were used for the investigations. The first part of the experiment was carried out as follows: The investigated sample was immersed in an electrochemical cell containing test seawater solution and kept in it until the steady-state potential had been established. Then, the oxide and surface films were removed from the sample surface using an installation for creating the juvenile surface of the metal. After switching the installation off, the surface and oxide films were restored. The potential was measured and plotted throughout the experiment (Figure 2). 


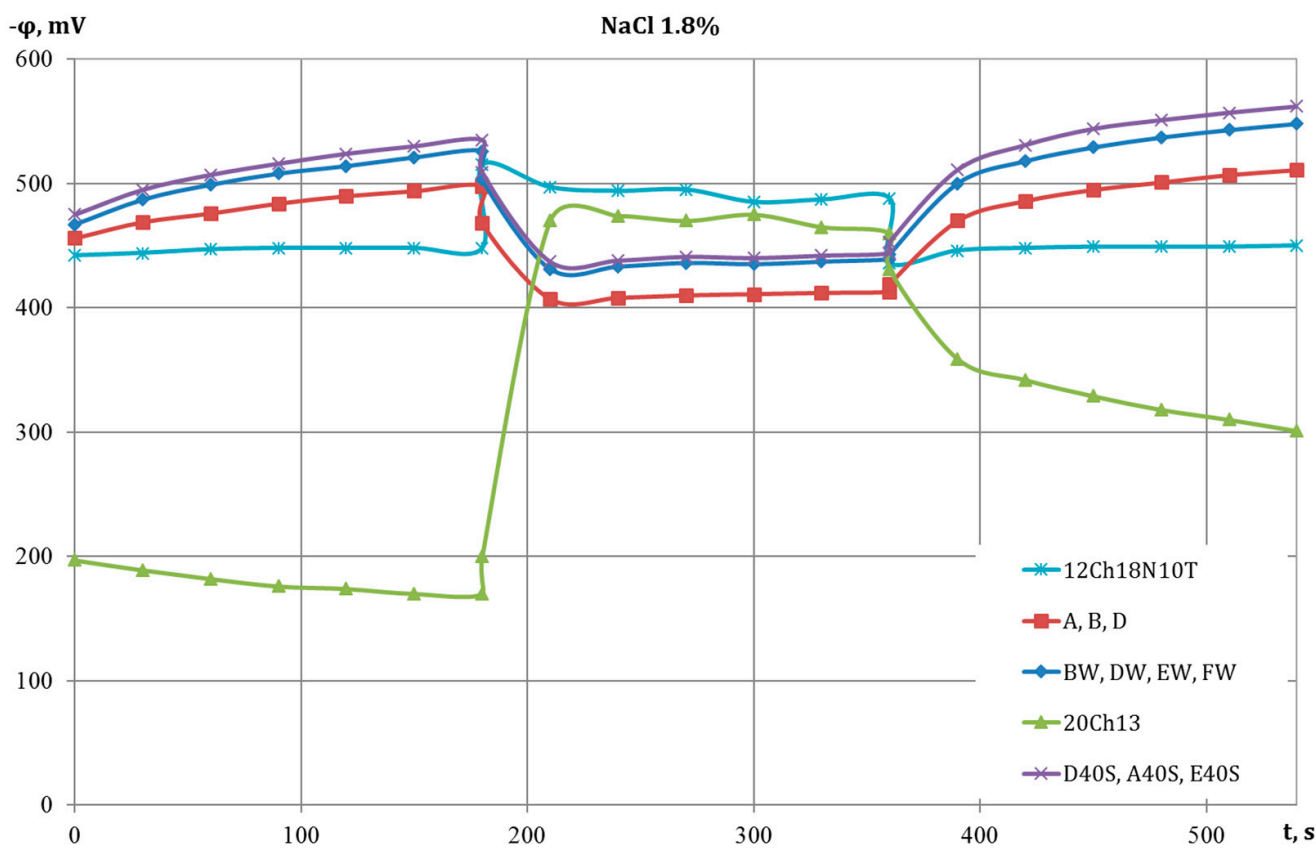

Figure 2. The first part of the experiment. Results.

A previously unknown phenomenon was discovered. During the formation of the juvenile surface, carbon steels and corrosion-resistant steels had the same characteristics at the apex of local defects, despite the differences between those steels in crystalline structure, mechanical properties, and chemical composition. Therefore, it was necessary to adjust the applied values of the protective potential of the impressed current cathodic protection against corrosion mechanical damages.

As the metal sample is being cathodically protected (polarized), i.e., as its surface is being saturated with negative charges from an external current source, the removal of excessive positive charges from its surface can be achieved; meanwhile, the anionic double electric layer is being removed as well. The potential at which the double electric layer has been removed from the metal surface is referred to as the uncharged surface potential. Further cathodic polarization of the metal results in recharging of its surface with the formation of the corresponding cathodic electric layer. The shift in the potential in the negative direction entails an increase in durability due to the surface charge reduction. The maximal durability is achieved at the uncharged surface potential. Thus, determination of the uncharged juvenile surface potential of shipbuilding steel in seawater is required to enable adjustment of the protective potential values to be specified for the cathodic protection systems of sea-going ships and structures to prevent local corrosion mechanical damages.

The developed test facility (Figure 3) enables the determination of the uncharged juvenile surface potential of shipbuilding steel in seawater [41]. The test facility for studying the electrochemical characteristics of hull structures of ships and floating facilities on the juvenile surface under cathodic polarization includes:

- Potentiostat-galvanostat IPC-Pro MF (1) with inputs for connecting an auxiliary electrode (2), a working electrode (3), and a reference electrode (4), which makes it possible to investigate the metal surface both with an oxide film and without an oxide film under cathodic polarization conditions;

- Auxiliary electrode (5), necessary for the implementation of the cathodic polarization of the working electrode;

- Electrochemical cell (6) with a model seawater solution;

- An installation for creating a juvenile surface of a sample (7), the feature of which is the ability to determine the potential of a metal without an oxide film (on a freshly formed metal surface, which simulates the state of the tip of local destruction); 
- Constant current source (8) to ensure continuous operation of the installation (7);

- Working electrode (9)—various types of steels (carbon, alloy, corrosion-resistant);

- Porous silver chloride reference electrode (10), the potential of which with respect to the hydrogen electrode at room temperature is equal to $200 \mathrm{mV}$;

- Voltmeter (11) to control the potential value on the metal surface;

- Computer (12) with installed IPC2000 software.

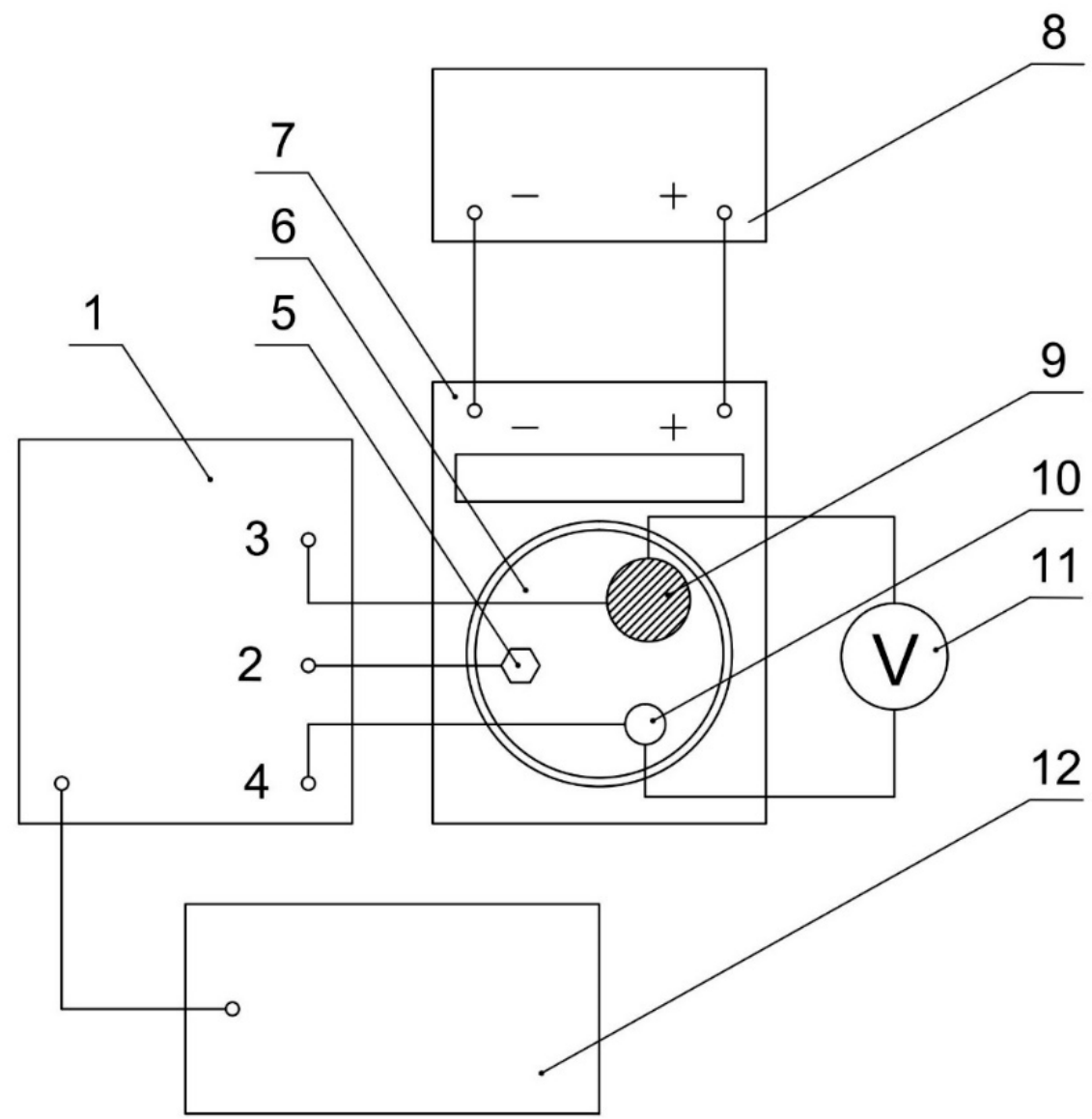

Figure 3. Test facility for studying the electrochemical characteristics of hull structures of ships and floating facilities on the juvenile surface under cathodic polarization [42].

A model seawater solution was used for the experiment. Powdered $\mathrm{NaCl}$ and distilled water were used to prepare the solution. Figure 4 shows the process of preparing a model solution of seawater with a salinity of $18 \%$, which requires $9 \mathrm{~g}$ of powdered $\mathrm{NaCl}$ and $500 \mathrm{~mL}$ of distilled water.

The second part of the experiment is described below. The investigated sample was immersed into an electrochemical cell containing test seawater solution and kept there until the steady-state potential had been established (Figure 5).

Then, the installation for creating the juvenile metal surface is started to continuously remove the oxide film (Figure 6). 

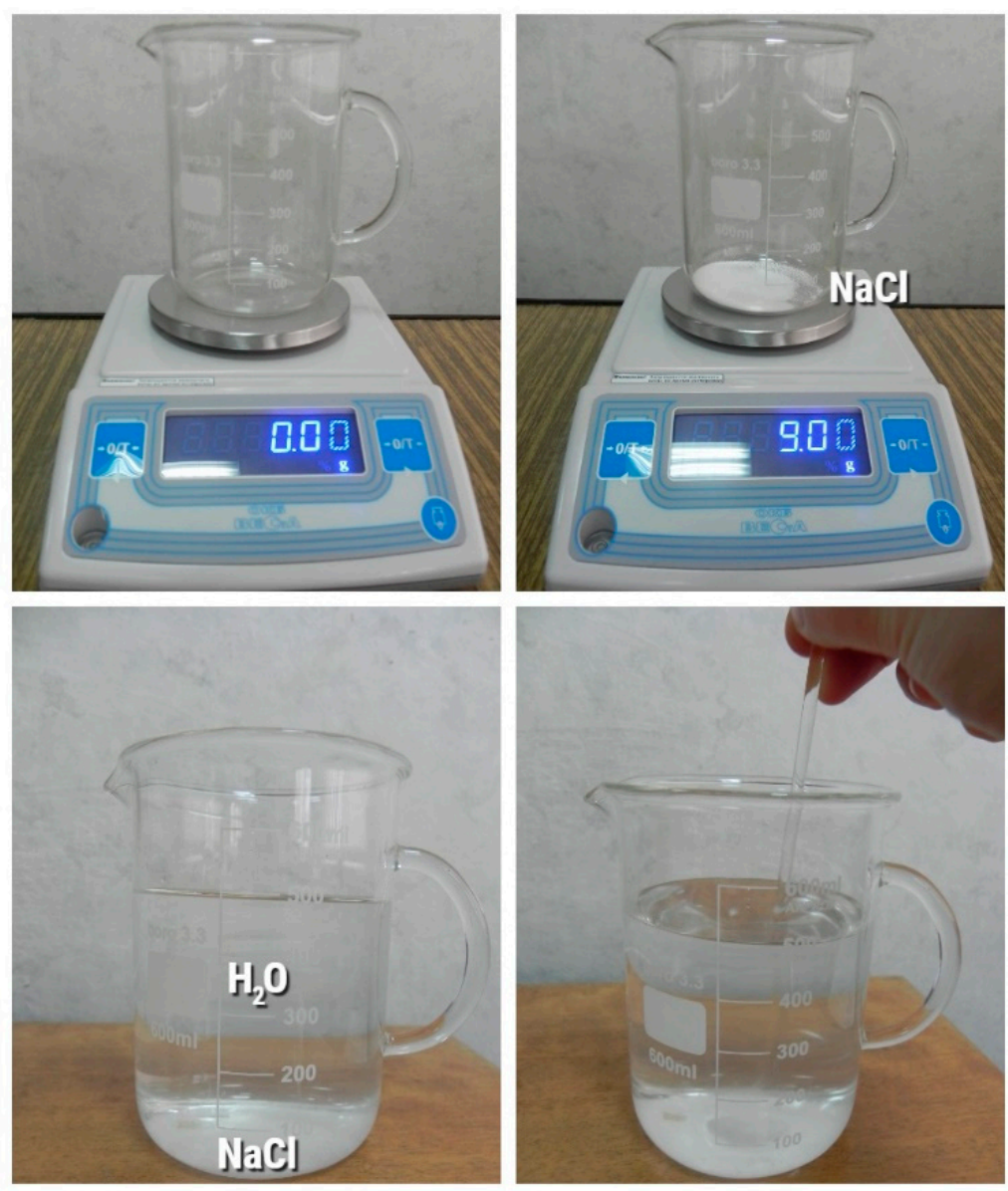

Figure 4. The process of preparing a model seawater solution.
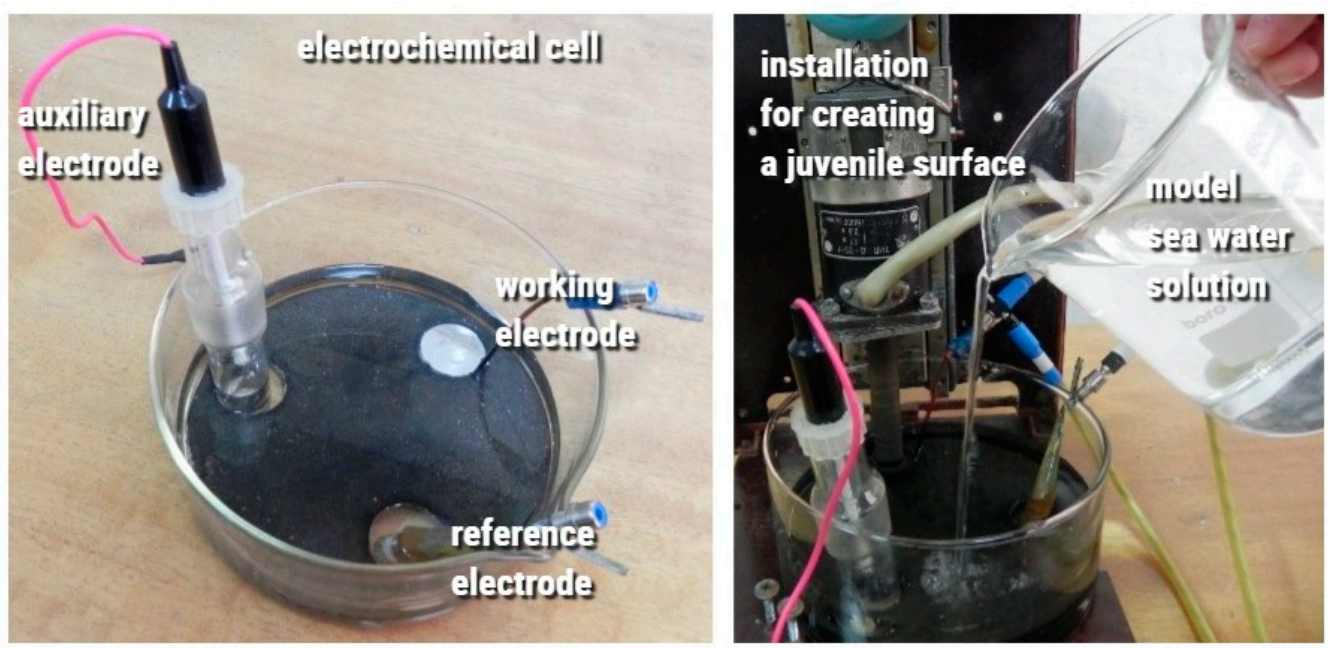

Figure 5. The preparation operation stage of the laboratory experiment. 

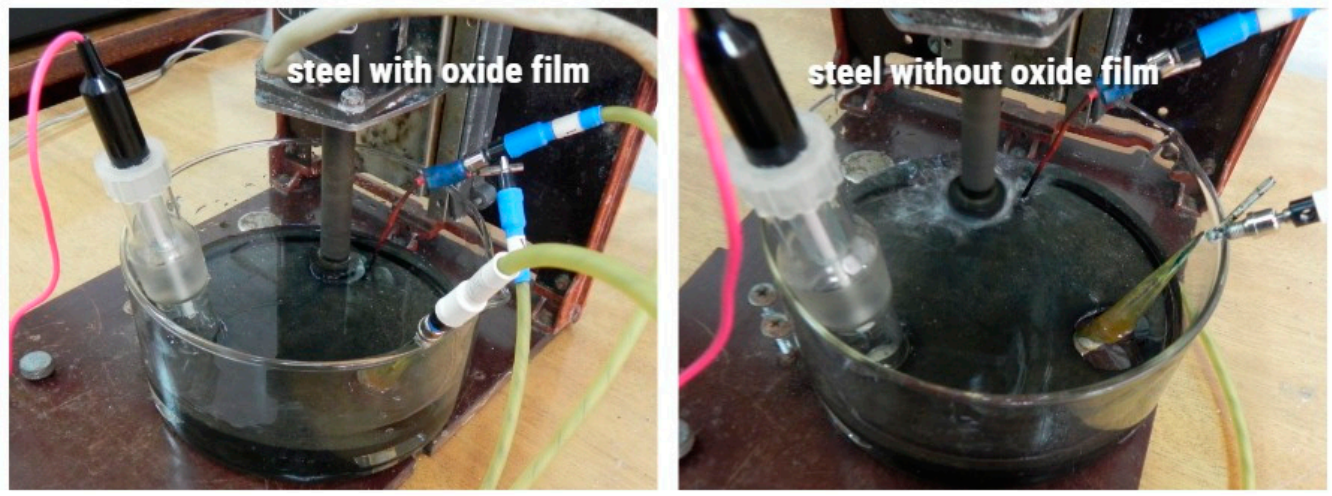

Figure 6. The laboratory experiment.

The potentiostat was used to cathodically polarize the test sample under the program preset by means of the computer programmer (Figure 7 ).

Experimental data (i.e., values of current and electrochemical potential) were recorded automatically by the computer throughout the experiment and plotted on the screen (Figure 8).

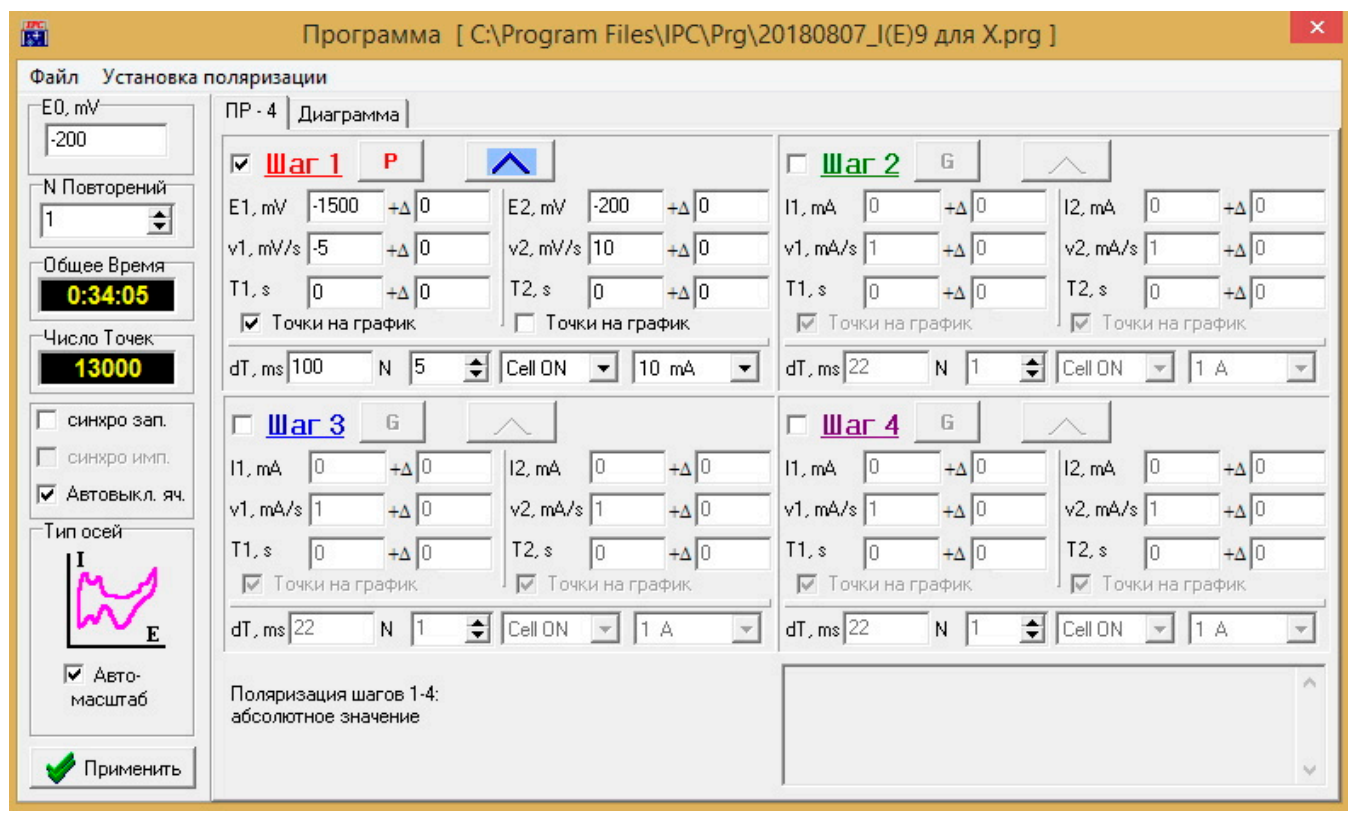

Figure 7. Program dialog box in IPC2000. 


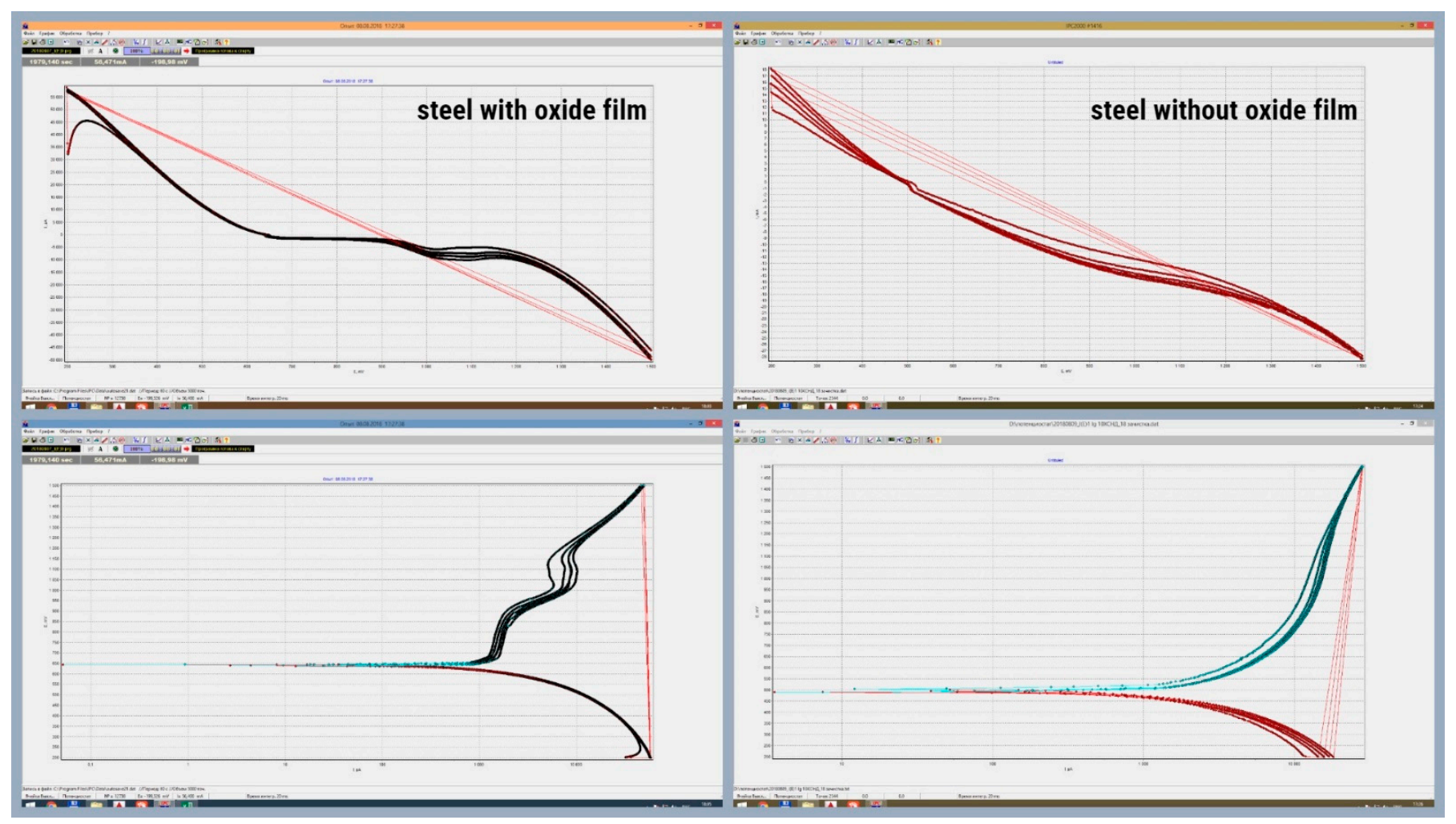

Figure 8. Experimental data.

\subsection{Procedure of Neural Network-Based Predicting}

However, experimental determination of the juvenile surface potential for all steels is impossible. Process automation and mathematical modeling are in active use in conducting investigations in various fields of science. For example, a mathematical model based on a combined boundary element was developed to determine the potential and protective current density [26]. Values of sufficient protective potential were obtained based on laboratory experiments to investigate the influence of flow rate on the cathodic protection criteria in seawater using potentiodynamic polarization, electrochemical impedance spectroscopy, and potentiostatic polarization [27]. Time and again, the importance of completing the cathodic protection system with a system controller to continuously control the protective current based on the determination of the protection potential has been proved [28]. In addition to controlling the protective current, the possibility of automatic movement of anode units and optimization of their location and number was considered to ensure an increase in the mandatory replacement period of the paint coating to 7 years [29]. An intelligent algorithm is often used to predict the polarization potential; for example, neural network-based control of the impressed current cathodic corrosion protection was proposed [33]. However, in the scientific background, there has been no consideration of the presence of the juvenile surface, nor has there been an account for it in neural network predicting so far. Therefore, local corrosion mechanical defects will continue to grow and possibly provoke structural failures.

To achieve the goal of the study, use was made of a multifactor neural network, where the input layer consists of eight neurons, i.e., the salinity of seawater and the percentages of carbon and alloying elements in steel. The output layer consists of two neurons, i.e., the potential of steel with oxide film (in $\mathrm{mV}$ ) and the potential of steel without oxide film, (in $\mathrm{mV}$ ). Results of the laboratory studies conducted in test seawater solutions varying in salinity were used to train the neural network for shipbuilding steels. An example of training sample data is presented in Table 1. 
Table 1. Sample for training a neural network.

\begin{tabular}{|c|c|c|c|c|c|c|c|c|c|c|}
\hline \multirow{2}{*}{ Steel Grade } & \multirow{2}{*}{$\begin{array}{c}\text { Salinity, } \\
\% \text { o }\end{array}$} & \multicolumn{7}{|c|}{ Content in Steel, \% } & \multicolumn{2}{|c|}{ Steel Potential, mV } \\
\hline & & Carbon & Manganese & Chromium & Silicon & Nickel & Copper & Titanium & With Oxide Film & Without Oxide Film \\
\hline & \multicolumn{8}{|c|}{ INPUT LAYER } & \multicolumn{2}{|c|}{ OUTPUT LAYER } \\
\hline$A, B, D$ & 18 & 0.18 & 0.53 & 0.30 & 0.23 & 0.30 & 0.30 & 0.00 & 494.00 & 410.17 \\
\hline BW, DW, EW, FW & 18 & 0.12 & 1.60 & 0.30 & 0.27 & 0.30 & 0.30 & 0.00 & 520.33 & 435.17 \\
\hline $20 \mathrm{Ch} 13$ & 18 & 0.21 & 0.80 & 13.00 & 0.80 & 0.00 & 0.00 & 0.00 & 171.33 & 469.00 \\
\hline 12Ch18N10T & 18 & 0.12 & 2.00 & 18.00 & 0.80 & 10.00 & 0.00 & 0.70 & 448.00 & 491.00 \\
\hline A, B, D & 30 & 0.18 & 0.53 & 0.30 & 0.23 & 0.30 & 0.30 & 0.00 & 505.33 & 432.33 \\
\hline BW, DW, EW, FW & 30 & 0.12 & 1.60 & 0.30 & 0.27 & 0.30 & 0.30 & 0.00 & 527.33 & 428.17 \\
\hline 20Ch13 & 30 & 0.21 & 0.80 & 13.00 & 0.80 & 0.00 & 0.00 & 0.00 & 167.33 & 458.00 \\
\hline D40S, A40S, E40S & 30 & 0.12 & 0.65 & 0.75 & 0.95 & 0.65 & 0.50 & 0.00 & 535.33 & 441.17 \\
\hline 12Ch18N10T & 30 & 0.12 & 2.00 & 18.00 & 0.80 & 10.00 & 0.00 & 0.70 & 437.33 & 504.00 \\
\hline
\end{tabular}


The numerical experiment was performed using a linear neural network, a radial basis neural network, and a generalized regression neural network.

The linear neural network is represented by a network without any intermediate layers and whose output layer contains only linear elements (i.e., elements with the linear activation function). Weights are related to matrix elements, while thresholds are related to components of the displacement vector. During operation, the network actually multiplies the vector of inputs by the matrix of weights and then adds the displacement vector to the obtained vector. Modeling is performed by approximation of the discriminant function or regression function with the use of a hyperplane. A globally optimal position can be found for this hyperplane by rather "simple" calculations, but adequate models for a number of realistic problems cannot be constructed this way [43]. A linear neural network is similar in architecture to a perceptron, but its transfer function is linear, unlike the perceptron whose transfer function is severely confining. This allows the network outputs to take on any values [44]. The linear transfer function calculates the output of a neuron simply by returning the value passed to it, $\alpha=w x+b$, where $b$ is the displacement vector. In the problem to be solved, this neuron is trained to learn the affine function of its inputs $x$. The linear network has one layer of hidden neurons connected to the outputs by the matrix of weights $w$.

The radial basis neural network is a type of neural network with an intermediate layer of radial elements and an output layer of linear elements. The radial basis neural network architecture uses the expression of the multidimensional Gaussian function [45]:

$$
\vec{h}(x)=\exp (-\alpha \cdot\|x-\vec{c}\|)
$$

where $\vec{c}$ is the vector of centers (i.e., coordinates of vertical symmetry axes) of the set of radially symmetric functions;

$\|x-\vec{c}\|$ is the norm of the difference vector of deviations of the input variable from the centers of radially symmetric functions and is calculated as the Euclidean distance $\|x-\vec{c}\|=\sqrt{\left(x-c_{1}\right)^{2}+\left(x-c_{2}\right)^{2}+\ldots+\left(x-c_{n}\right)^{2}}$;

$\alpha=\frac{1}{2 r^{2}}$ is the parameter related to the scattering radius of the input variables $r$.

The radial basis neural network consists of two hidden layers of neurons and the composition of the investigated shipbuilding steel. The input of the first layer contains variables that characterize the salinity of seawater in the region of investigation $x_{1}$ and the composition of the investigated shipbuilding steel $x_{2}, x_{3}, \ldots, x_{n}$. The outputs of the first layer are activated by the set of radially symmetric function (1) $h_{1}, h_{2}, \ldots, h_{n}$ and process the vector of input values to determine the degree of proximity of each of them to the centers of radially symmetric functions. The outputs of the second layer neurons (i.e., outputs of the whole neural network) are the linear combinations of the first layer outputs.

A generalized regression neural network is a subspecies of Bayesian networks, where a kernel approximation is used for the regression [43].

\section{Results}

\subsection{The Numerical Experiment}

As a first approximation of the numerical experiment, adequately operating neural networks were identified. However, the relative error exceeded the maximum allowable error in predicting the potential of corrosion-resistant steels.

The numerical values of the abscissa axis (Figure 9) correspond as follows:

1. Potential of $12 \mathrm{Ch} 18 \mathrm{~N} 10 \mathrm{~T}$ steel with an oxide film, $\mathrm{mV}$;

2. Potential of $12 \mathrm{Ch} 18 \mathrm{~N} 10 \mathrm{~T}$ steel without oxide film, $\mathrm{mV}$;

3. Potential of $\mathrm{A}, \mathrm{B}$, and $\mathrm{D}$ steels with an oxide film, $\mathrm{mV}$;

4. Potential of $\mathrm{A}, \mathrm{B}$, and $\mathrm{D}$ steels without oxide film, $\mathrm{mV}$;

5. Potential of BW, DW, EW, and FW steels with an oxide film, $\mathrm{mV}$; 
6. Potential of BW, DW, EW, and FW steels without oxide film, mV;

7. Potential of $20 \mathrm{Ch} 13$ steel with an oxide film, $\mathrm{mV}$;

8. Potential of 20Ch13 steel without an oxide film, mV;

9. Potential of D40S, A40S, and E40S steels with an oxide film, $\mathrm{mV}$;

10. Potential of D40S, A40S, and E40S steels without oxide film, mV.
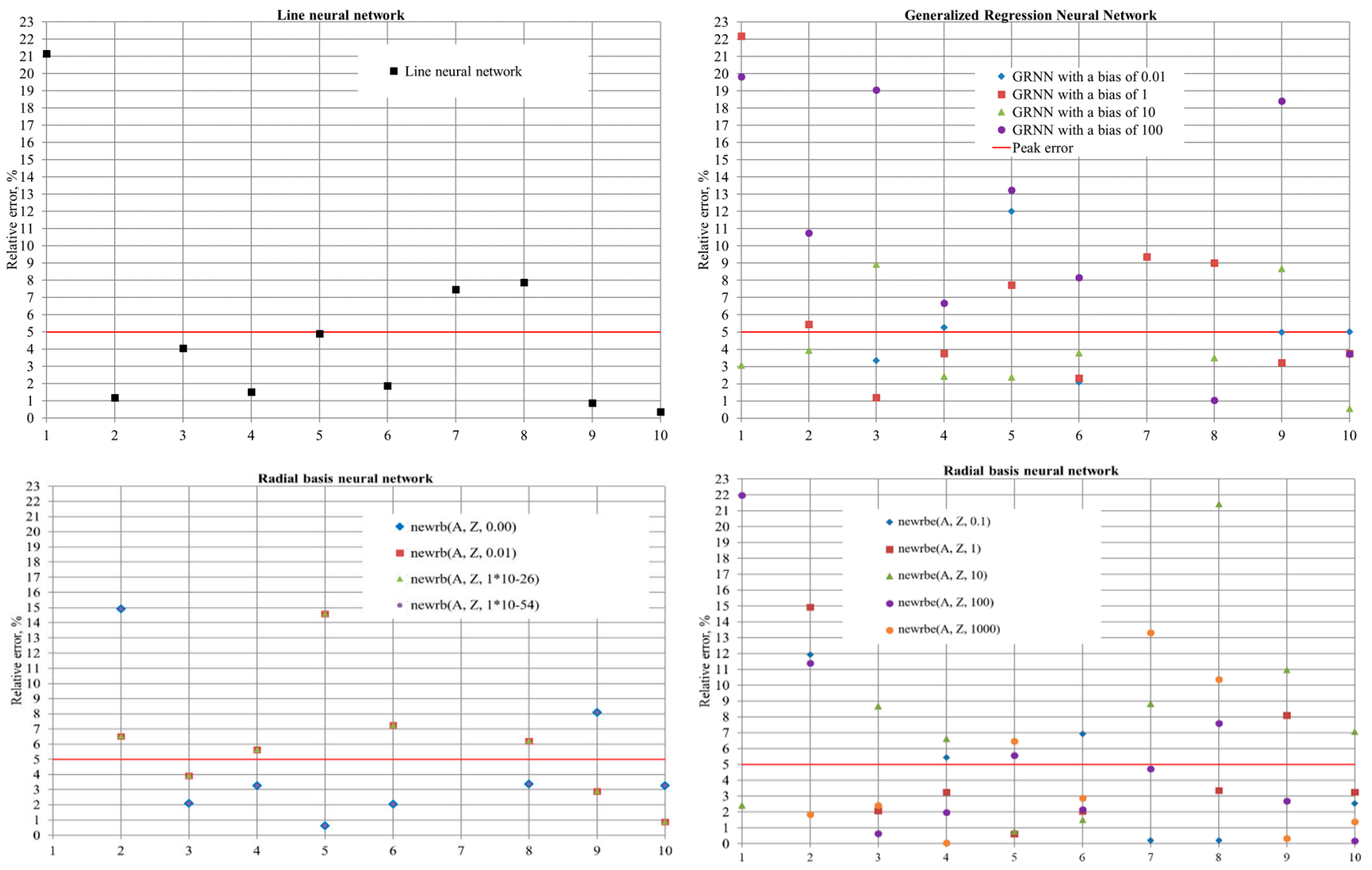

Figure 9. The first approximation of the numerical experiment.

In order to improve the quality of predicting the corrosion-resistant steel potential, the second approximation numerical experiment was conducted by dividing the training sample based on the corrosion resistance of the steels. As a result, the accuracy of potential prediction was increased by $13-20 \%$. However, the accuracy of potential prediction for corrosion-resistant steels was still no higher than $58 \%$.

Since the corrosion resistance of steels is affected by the presence of the alloying element, i.e., chromium [46], two samples made on the basis of the quantitative content of chromium in steel were used to reduce the relative error for the third approximation numerical experiment (Figure 10). 


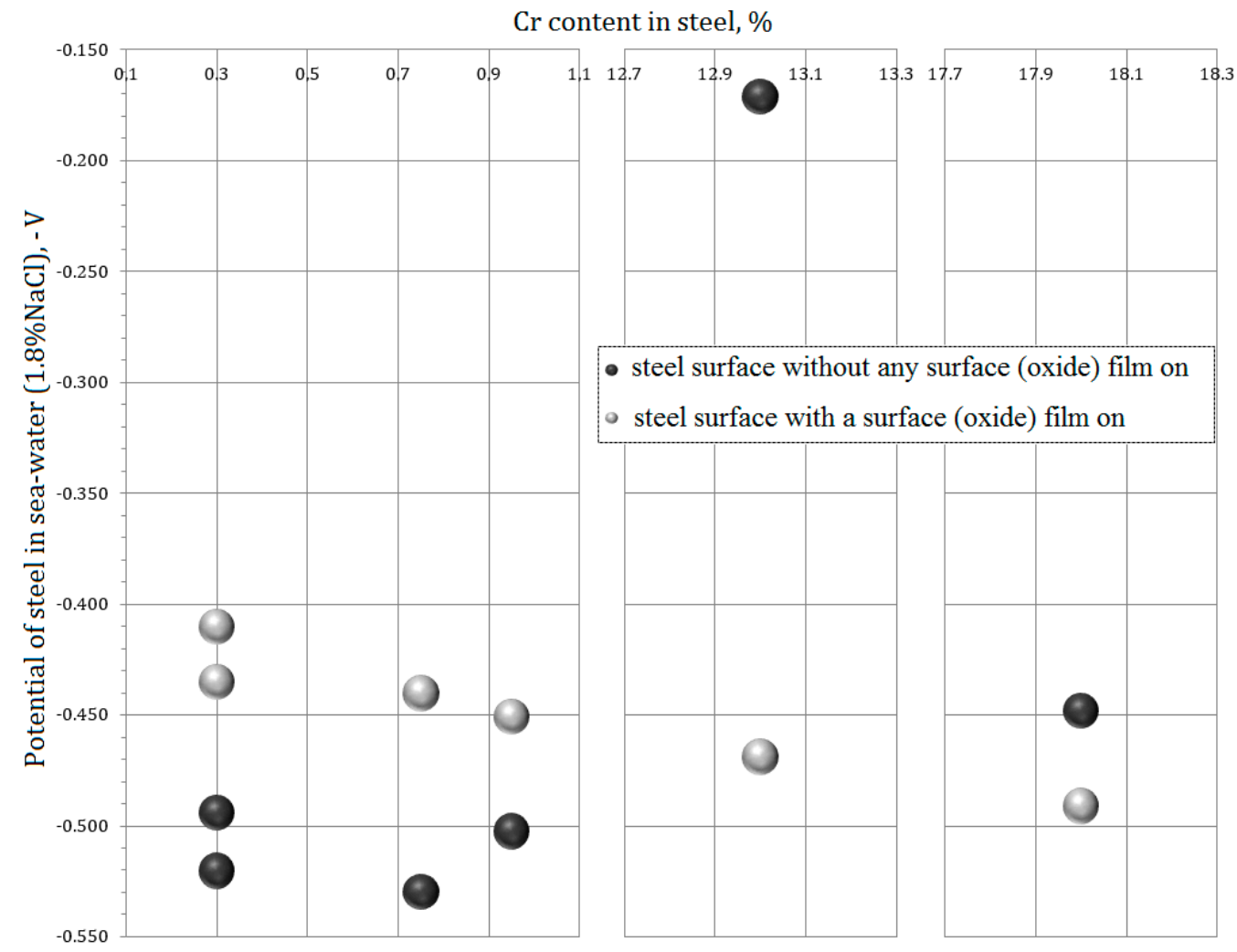

Figure 10. The relationship between chrome content and potential of seawater $(1.8 \% \mathrm{NaCl})$-immersed steel both with a surface (oxide) film and without it.

The experimental study yielded the recommended neural networks depending on the percentage of the alloying element, i.e., chromium [47]. The reference parameters, i.e., the potential of steel with oxide film and the potential of steel without oxide film, were obtained this way.

The analysis of the existing studies indicates that the uncharged surface potential of shipbuilding steels with oxide film is in the range of -870 to $-900 \mathrm{mV}$ without taking into account the juvenile surface. The protective potential, which provides the potential of uncharged steel surface on the juvenile surface (i.e., surface without oxide film at the apex of local defects), is required to predict for the correct operation of the cathodic protection system against corrosion mechanical damages of hull structures of ships and floating facilities.

To determine the values of potentials of shipbuilding steels on the juvenile surface under cathodic polarization, a series of laboratory experiments was carried out on specifically designed equipment, i.e., the test facility for studying the electrochemical characteristics of ship hull structures and floating facilities on the juvenile surface under cathodic polarization. An example of the results obtained is presented in Tables 2 and 3. 
Table 2. Corrosion potential of shipbuilding steels with an oxide film.

\begin{tabular}{cccccc}
\hline Salinity, \%o & A, B, D & BW, DW, EW, FW & D40S, A40S, E40S & 20Ch13 & 12Ch18N10T \\
\hline 18 & 636.07 & 660.26 & 638.99 & 200.49 & 478.22 \\
\hline 20 & 493.43 & 514.15 & 553.77 & 385.78 & 325.78 \\
\hline 22 & 575.12 & 635.28 & 606.48 & 465.81 & 466.03 \\
\hline 24 & 650.62 & 657.35 & 639.09 & 462.42 & 497.47 \\
\hline 26 & 629.07 & 649.78 & 635.22 & 410.56 & 467.04 \\
\hline 28 & 644.36 & 645.67 & 618 & 470.63 & 492.39 \\
\hline 30 & 633.08 & 636.95 & 610.59 & 495.15 & 464.36 \\
\hline
\end{tabular}

Table 3. Corrosion potential on the juvenile surface of steel.

\begin{tabular}{cccccc}
\hline Salinity, \% & A, B, D & BW, DW, EW, FW & D40S, A40S, E40S & 20Ch13 & 12Ch18N10T \\
\hline 18 & 446.3 & 472.12 & 490.19 & 545.32 & 576.19 \\
\hline 20 & 495.15 & 392.2 & 381.79 & 519.62 & 479.24 \\
\hline 22 & 494.7 & 470.85 & 505.14 & 562.11 & 564.47 \\
\hline 24 & 556.77 & 530.59 & 527.65 & 574.22 & 506.96 \\
\hline 26 & 543.53 & 521.64 & 478.58 & 382.73 & 538.04 \\
\hline 28 & 535.9 & 476.09 & 483.53 & 413.32 & 454.95 \\
\hline 30 & 457.63 & 517.12 & 483.49 & 475.54 & 517.37 \\
\hline
\end{tabular}

The values of potentials were obtained for shipbuilding steels with an oxide film and on the juvenile surface under cathodic polarization; corrosion potential varying depending on the presence of an oxide film on the surface of shipbuilding steel was determined (Figure 11). As can be seen from graphs plotted by the potentiodynamic study data, the change from anode current to cathode current occurs at the minimal value of $\lg (\mathrm{I})$, which corresponds to the peaks in the graphs and the current of $\mathrm{I}=0 \mathrm{~mA}$.

The corrosion potential is the value of potential obtained at those peaks. The results demonstrate the variation of potential depending on the presence of an oxide film on the surface of shipbuilding steel. Determination of the difference between the obtained corrosion potentials is the next step in processing the laboratory experiment data to determine the potential of shipbuilding steels with an oxide film and on the juvenile surface in test seawater solutions.

Therefore, to predict the protective potential of the underwater part of ships and ocean engineering facilities, it is necessary to adjust the previously obtained potential of steel on the juvenile surface by the value of the corrosion potential difference in order to obtain the potential of the uncharged surface on the juvenile surface of steel. 


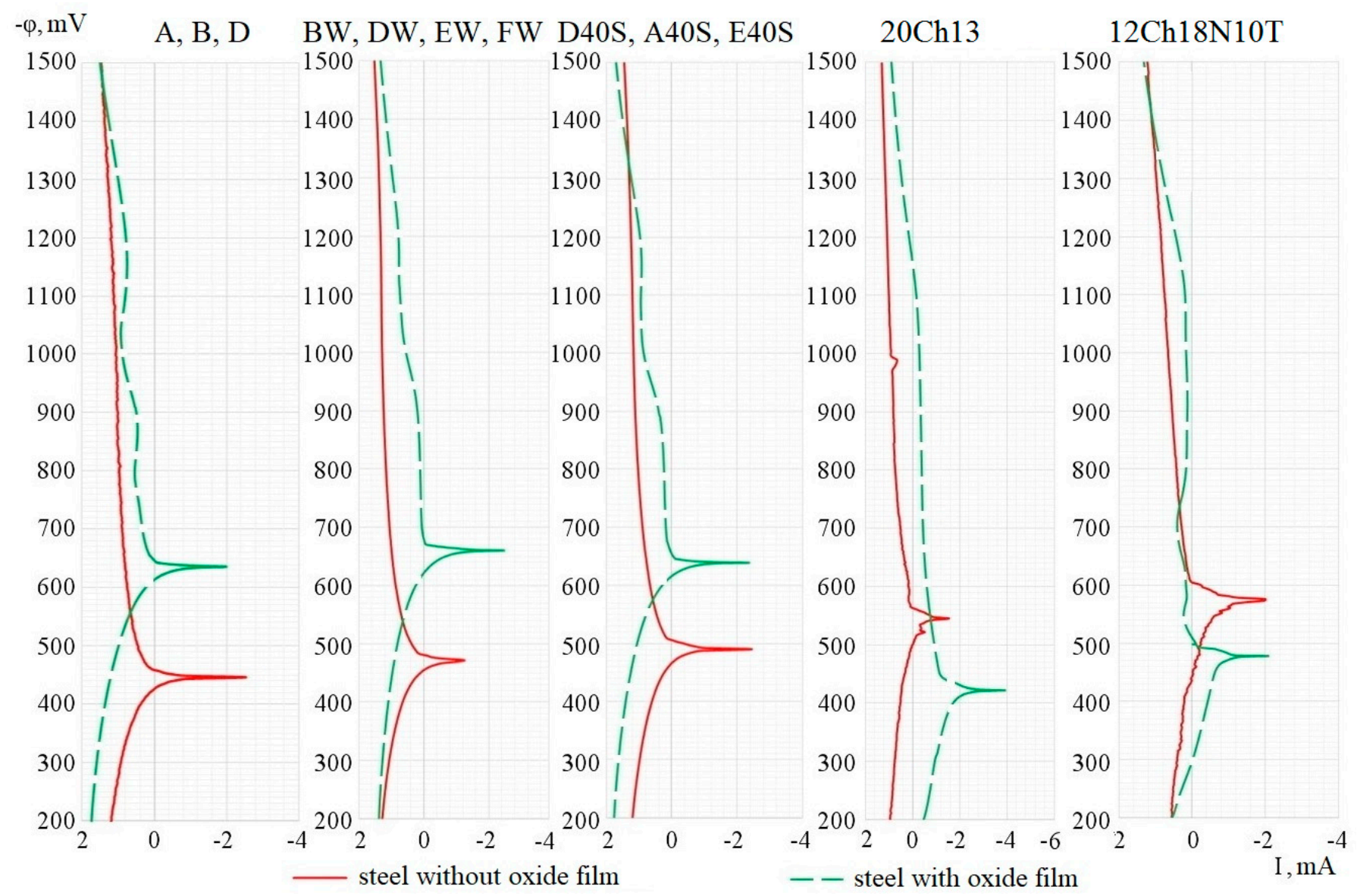

Figure 11. Potentiodynamic studies of steels in $\mathrm{NaCl} 1.8 \%$.

\subsection{A Program for Predicting the Protective Potential}

On the basis of the conducted investigations, a program was developed to predict the protective potential of the steel underwater part of ships and other ocean engineering facilities, which provides the potential of the uncharged steel surface, including the case of the juvenile surface. The main function of the program is to improve the quality of cathodic protection of hull structures of ships and floating facilities from corrosion mechanical damages with the possibility of preventing the spread of local damages on the basis of an accurate selection of the protective potential, taking into account the juvenile surface.

The program prompts the user for the salinity of seawater and the percentage of carbon and alloying elements in the steel. Next, the type of neural network for prediction is determined based on the amount of chromium. As the authors identified, a linear neural network should be used for low-alloy steels with chromium content lower than $5 \%$.

For steels with a chromium content of $5-15 \%$, it was found that a radial basis neural network with a minimum number of neurons should be applied.

For high-alloyed steels with chromium content higher than $15 \%$, it was found that a generalized regression neural network should be used.

As a result of running the program, the user obtains the value of protective potential for a given steel. The developed program can be installed at the facility to be protected with modification for specific operating conditions (e.g., seawater salinity, steel category of hull structures) and equipped with a user-friendly interface (in terms of, e.g., the language and the compliance with the operating system used onboard the ship).

A methodology was developed to predict the parameters of protection of hull structures of ships and floating facilities against local corrosion mechanical damage based on the application of neural network technologies, which enables the determination of the 
juvenile surface potential for all steels, including those under development, without the need to conduct time-consuming laboratory experiments.

\section{Discussion}

The suggested protection method allows monitoring reference parameters and controlling protective potential by setting the value for the protection of hull structures against general corrosion or comprehensively, i.e., taking into account local corrosion stress damages. Thus, stabilization of cathodic polarization is achieved by shifting the potential towards the negative direction until the double electric layer on the juvenile surface disappears, and the achieved potential's value is also maintained. In that condition of the metal, the governing factor is a specific adsorption that will not provoke corrosion, fatigue, cracking, or the occurrence of the Rebinder effect. In that process, electrostatic adsorption (of chlorine anions) does not take place, which contributes to the longevity of hull structures of ships and floating facilities.

Additional beneficial effects of using cathodic protection by impressed current at the uncharged surface potential on the juvenile surface of steel, positively influencing the durability of hull structures of ships and floating facilities, have been determined.

The Rules for Classification and Construction of Sea-Going Ships by the Classification Society "Russian Maritime Register of Shipping" [48] say that, in performing structural design of hull structures, the reduction in plate thickness due to corrosion wear experienced by the middle of the service life shall be taken into account. The corrosion allowance, in $\mathrm{mm}$, is set for the structures whose planned service life exceeds 12 years and is determined by the following formula:

$$
\Delta \mathrm{S}=\mathrm{u} \cdot(\mathrm{T}-12),
$$

where $\mathrm{u}$ is the average annual reduction in thickness of the member, in mm per annum, due to corrosion wear or tear and $\mathrm{T}$ is the planned service life of the structure, in years; unless specified otherwise, $\mathrm{T}$ shall be taken equal to 24 years.

The average annual reduction in thickness of hull structural elements of the ship's outer shell shall be determined based on the division of all ships depending on corrosion wear conditions provided for by the Register Rules into two groups: Group I-dry-cargo ships and similar ships as regards the service conditions; Group II—-tankers, bulk carriers, combination ships, and similar ships as regards the service conditions.

However, the use of the proposed method of protecting hull structures of ships and floating facilities by cathodic polarization from local forms of corrosion mechanical damages at the potential of the uncharged surface on the juvenile surface of steel makes it possible to achieve the reduction in steel corrosion rate in seawater, which will subsequently reduce the value of the average annual reduction in steel thickness, $\mathrm{u}, \mathrm{mm} / \mathrm{year}$, in the area of the outer skin of the ship and the underwater part of floating facilities.

Thus, the value of corrosion allowance, $\Delta S$, will be decreased, enabling the use of steel of lower thickness for the elements of hull structures, significantly reducing the weight of the heavy weight group "Hull". Therefore, for cargo ships, the weight of the carried cargo can be increased, which will contribute to economical effectiveness.

The proposed method of protection allows the parameters to be monitored and the protective potential to be controlled by setting the value for the protection of hull structures from general corrosion or in an all-encompassing way, that is, taking into account local corrosion mechanical damages. The accuracy of the applied value of protective potential will allow increasing the interdocking period of the hulls of ships and floating facilities, where the possibility of docking is provided.

The use of flush-mounted anode units (type AU-2M and AU-3M anodes ([49] or [39])) reduces the influence of cathodic corrosion protection on ship motion resistance, while anode protection arrangement is fixed to the ship's hull and thus initiates an additional resistance. Resistance is also affected by microbial products that contribute to the fouling of the underwater part of the hulls of ships and floating facilities. The use of the proposed method of protection can have a beneficial effect on the fouling control of hull structures of 
ships and floating facilities. However, to verify that, a detailed study of the interaction of the processes contributing to the fouling and those occurring during cathodic polarization of steel hull structures is required [50].

The need for replacement of protection elements during the entire service life of hull structures of ships and floating facilities is avoided, with a possible prolongation of that period, taking into account that the anode units' service life specified by their designers is at least 30 years.

The above-mentioned beneficial effects of cathodic protection by impressed current at the uncharged surface potential on the juvenile surface of steel allow increasing the durability of hull structures of ships and floating facilities, thus ensuring the possibility of their normal operation upon the expiration of the design service life, providing the proper maintenance. The quantitative assessment of those beneficial effects is a direction for further research.

\section{Conclusions}

As a result of scientific research based on the use of neural network technology, a model of cathodic protection of marine vessels and ocean engineering facilities from local forms of corrosion mechanical damages at the uncharged surface potential on the juvenile surface of steel is developed. Protective potential ranges from -765.46 to $-754.45 \mathrm{mV}$ for hull structures of ships and floating facilities fabricated from steel grades A, B, D, BW, DW, $\mathrm{EW}$, and $\mathrm{FW}$; from -963.7 to $-933.7 \mathrm{mV}$ for corrosion-resistant steels with chrome content of up to $15 \%$; and from -983.15 to $-953.15 \mathrm{mV}$ for corrosion-resistant steels with chrome content higher than $15 \%$.

The accuracy of the applied value of protective potential will allow increasing the interdocking period of the hulls of ships and floating facilities, where the possibility of docking is provided.

Author Contributions: The authors contributed to this research study as follows: conceptualization, V.K., A.R., O.I., S.C.; methodology, V.K., A.R.; software, A.Z., O.I.; validation, S.C., A.R., V.K.; formal analysis, O.I., V.K., A.R.; investigation, V.K., A.R., O.I., A.Z., S.C.; resources, V.K., A.R., O.I., A.Z., S.C.; data curation, A.R., S.C.; writing—original draft, A.R., O.I.; visualization, O.I., A.R.; supervision, V.K., S.C.; funding acquisition, S.C., A.Z. All authors have read and agreed to the published version of the manuscript.

Funding: The research was partially funded by the Ministry of Science and Higher Education of the Russian Federation as part of the World-Class Research Center program: Advanced Digital Technologies (contract No. 075-15-2020-903 dated 16 November 2020).

Conflicts of Interest: The authors declare no conflict of interest. The company Central Design Bureau "Corall" JSC had no role in the design, collection, analyses, or interpretation of data, the writing of the manuscript, or the decision to publish the results.

\section{References}

1. Ignatovich, V.S.; Rodkina, A.V. Problems of the strength of the hull of transport ships in case of death as a result of a hull fracture. Sci. Work. Azerbaijan State Marit. Acad. 2015, 2, 43-51.

2. Kuzmin, Y.L.; Stavitsky, O.A.; Podshivalov, A.V. Parameters and operating experience in arctic conditions of cathodic protection systems against corrosion-erosion destruction of the hulls of nuclear icebreakers. Shipbuilding 2015, 6, 33-37.

3. Disasters 2013 Chronicles. Available online: http:/ / www.odin.tc/2013/molcomfortru.htm (accessed on 20 April 2021).

4. In the Arabian Sea, a Ship with Russian Sailors Broke into Two Parts. Available online: https:/ /www.amic.ru/news/223492/ (accessed on 20 June 2021).

5. Investigation Report on Structural Safety of Large Container Ships. Available online: https://www.classnk.or.jp/hp/pdf/news/ Investigation_Report_on_Structural_Safety_of_Large_Container_Ships_EN_ClassNK.pdf (accessed on 22 June 2021).

6. Boytsov, G.V.; Paliy, O.M. Strength Standards of Sea Vessels; Krulova: Petersburg, Russia, 1988.

7. Khromov, A.I.; Bukhanko, A.A.; Stepanov, S.L.; Kocherov, E.P. Fracture of Plastic Bodies. Deformations Concentrators, Fracture of Nano and Engineering Materials and Structures. In Proceedings of the 16th European Conference of Fracture, Alexandroupolis, Greece, 3-7 July 2006; Volume 125.

8. SHELL BEARD. Available online: http://sudavmore.ru/doki/rakushechnaya-boroda/ (accessed on 28 June 2021). 
9. Kushnir, V.; Dushko, V.; Kramar, V. Impact of surface gravity waves on coastal ocean-technical facilities. East. Eur. J. Enterp. Technol. 2013, 5, 36-41.

10. Seven Worst Drilling Platform Accidents. Available online: https://www.vesti.ru/doc.html?id=1168280 (accessed on 22 June 2021).

11. Deepwater Horizon. Available online: http://economic-definition.com/Plants_and_soobruzheniya/Neftyanaya_platforma_ Deepwater_Horizon_Glubokovodnyy_Gorizont_eto.html (accessed on 29 June 2021).

12. Kushnir, V.M.; Dushko, V.R.; Fedorov, S.V. The impact of the marine environment on the technical systems of shelf development. Mar. Pollut. Bull. 2021, 169, 112577.

13. Karpenko, G.V.; Pistun, I.P.; Litvin, A.K. Effect of anodic and cathodic processes on the low-cycle fatigue strength of high-strength steel subjected to a corrosive solution. Sov. Mater. Sci. 1978, 13, 671-672. [CrossRef]

14. Vitvits'kii, P.M.; Karpenko, G.V. Size and equilibrium state of initial and developed cracks with cohesive interaction between the surfaces. Mater. Sci. 1994, 29, 355-361. [CrossRef]

15. Karpenko, G.V.; Kobzaruk, A.V.; Balatskii, L.T. Resistance of chromium-nickel-molybdenum steel to corrosion and corrosionfatigue in seawater. Sov. Mater. Sci. 1979, 15, 232-235. [CrossRef]

16. Ryabchenkov, A.V.; Gerasimov, V.I.; Kharina, I.L.; Ershov, N.S. Electrochemical methods of determining the liability of chromium steels to pitting corrosion in solutions of chlorides. Prot. Met. 1983, 19, 332-335.

17. Ozhiganov, Y.G.; Goryachko, Y.S.; Shevchenko, O.F.; Litvinov, V.E.; Gubarev, M.K. Influence of fine crystal structure on the susceptibility of austenitic steel to stress corrosion cracking in seawater. Prot. Met. 1978, 14, 68-70.

18. Yarema, S.Y. Test method for the determination of crack-growth rates and crack growth resistance under cyclic loading. Mater. Sci. 1995, 30, 706-717. [CrossRef]

19. Schijve, J.; Yarema, S.Y. Fatigue of structures and materials in the 20th century and the state of the art. Mater. Sci. 2003, 39, 307-333. [CrossRef]

20. Zimina, T.Y.; Rakoch, A.G.; Panov, M.K.; Oshe, E.K.; Fokin, M.N. The effect of cold straining on the initial stages of air oxidation of chromium steel. Prot. Met. 1997, 33, 53-57.

21. Kuzmin, Y.L.; Laschevskii, V.O.; Kalinin, G.Y. Effect of cathodic polarization on mechanical characteristics of high-strength nitrogen-containing steel in seawater. Inorg. Mater. Appl. Res. 2016, 2016, 899-903. [CrossRef]

22. Rebinder, P.A.; Shchukin, E.D. Surface phenomena in solids during the course of their deformation and failure. Sov. Phys. Uspekhi 1973, 15, 533-554. [CrossRef]

23. Baeckmann, W.; Schwenk, W.; Prinz, W. Handbook of Cathodic Corrosion Protection; Elsevier: Amsterdam, The Netherlands, 1997.

24. Morley, J.; Chandler, K.A.; O’Brien, J.E. Protection of steel from corrosion. Rev. Bras. Tecnol. 1980, 9, 75-81.

25. Gorynin, I.V.; Kuzmin, Y.L.; Legostaev, Y.L.; Malyshevsky, V.A.; Makarov, E.F. Method of Protection against Erosion-Corrosion Destruction of Offshore Oil and Gas Production Facilities in Ice. Conditions. Patent No 2070620, 5 January 1997.

26. Mujezinović, A.; Turković, I.; Martinez, S.; Milojković, S. Modelling of the Cathodic Protection System with Dynamic NonLinear Polarization Characteristics. In Proceedings of the 25th International Conference on Information, Communication and Automation Technologies, ICAT 2015, Sarajevo, Bosnia, 29-31 October 2015. [CrossRef]

27. Kim, J.-H.; Kim, Y.-S.; Kim, J.-G. Cathodic protection criteria of ship hull steel under flow condition in seawater. Ocean Eng. 2016, 115, 149-158. [CrossRef]

28. Mainier, F.B.; Perassolli, V. Ship hull corrosion caused by default and lack of maintenance on the impressed current cathodic protection. IOSR J. Eng. 2014, 4, 34-39. [CrossRef]

29. Xing, S.H.; Li, Y.; Song, H.Q.; Yan, Y.G.; Sun, M.X. Optimization the quantity, locations and output currents of anodes to improve cathodic protection effect of semi-submersible crane vessel. Ocean Eng. 2015, 113, 144-150. [CrossRef]

30. Han, E.; Chen, J.; Su, Y.; Liu, M. Corrosion protection techniques of marine engineering structure and ship equipment-current status and future trend. Mater. China 2014, 33, 65-76. [CrossRef]

31. Zelentsov, D.G.; Ivanova, A.P. Application of neuronetwork models for solvingtasks of durability prediction of corrodible beam constructions. Nauk. Visnyk Natsionalnoho Hirnychoho Universytetu 2015, 4, 51-56.

32. Zelentsov, D.G.; Novikova, L.V. Improvement of the efficiency of numerical methods employed in corrosive constructions research. Nauk. Visnyk Natsionalnoho Hirnychoho Universytetu 2015, 3, 125-130.

33. Kadhim, H.; L-Shareefi, M.A. Neural Network Corrosion Control by Impressed Cathodic Protection; University of Technology: Baghdad, Iraq, 2009.

34. Semenova, I.V.; Florianovich, G.M.; Khoroshilov, A.V. Corrosion and Protection against Corrosion; FIZMAT: Moscow, Russia, 2010; $416 \mathrm{p}$.

35. World Maritime News. Available online: https:// worldmaritimenews.com/ (accessed on 10 June 2021).

36. DBC 39-84 Cathodic Protection against Corrosion of Equipment and Metal Structures of Hydraulic Structures. Available online: https: / / cathwell.com/priniples-of-cpppppp/ (accessed on 1 July 2021).

37. GOST 26501-85 Marine Hulls. General Requirements for Electrochemical Protection. Available online: https://gostperevod.ru/ gost-26501-85.html (accessed on 2 June 2021).

38. GD 31.35.07-83 Guidelines for Electrochemical Corrosion Protection of Metal Structures of Offshore Hydraulic Structures in the Underwater Area. Available online: https:/ /www.vgb.org \T1 \guilsinglright_wind_download (accessed on 10 June 2021). 
39. Cathelco ICCP Hull Corrosion Protection Systems. Available online: http://www.cathelco.com.sg/iccp/ (accessed on 10 June 2021).

40. Kramar, V.; Dushko, V.; Rodkina, A.; Zaiets, A. Influence of Stress-Corrosion Fractures on Potential of Ship-Building Metals in the Sea Water. In Proceedings of the 25th DAAAM International Symposium, Vienna, Austria, 23-30 November 2014; pp. 1068-1074. [CrossRef]

41. Rodkina, A.V.; Ivanova, O.A.; Kramar, V.A.; Dushko, V.R. Experimental studies of shipbuilding steels at cathodic polarization. Mar. Intell. Technol. Sci. J. 2020, 49, 72-83.

42. Rodkina, A.V.; Ivanova, O.A.; Dushko, V.R.; Kramar, V.A. Complex for the Study of Electrochemical Characteristics of Hull Structures of Ships and Floating Technical. Structures. Patent No 2695 961, 20 January 2019.

43. Speckt, 1991; Patterson, 1996; Bishop. 1995. Available online: http://statsoft.ru/home/textbook/default.htm (accessed on 20 June 2021).

44. Linear Neural Networks. Available online: https://www.mathworks.com/help/deeplearning/ug/linear-neural-networks.html? s_tid=srchtitle\#responsive_offcanvas (accessed on 19 June 2021).

45. Nejronnye Seti, Funktsij. Available online: https://neuronus.com/theory/nn/954-nejronnye-seti-na-osnove-radialnosimmetrichnykh-funktsij.html (accessed on 15 June 2021).

46. Kramar, V.; Dushko, V.; Rodkina, A.; Alchakov, V. Neural Network Modeling the Potential of Steels with Different Chrome Content. In Proceedings of the 26th DAAAM International Symposium, Zadar, Croatia, 21-24 October 2016; pp. 1059-1067. [CrossRef]

47. Osadchiy, A.; Kamenev, A.; Saharov, V.; Chernyi, S. Signal Processing Algorithm Based on Discrete Wavelet Transform. Designs 2021, 5, 41. [CrossRef]

48. Russian Maritime Register of Shipping, 2019. Rules for the Classification and Construction of Sea-Going Ships. Available online: https:/ /lk.rs-class.org/regbook/rules?ln=ru (accessed on 20 June 2021).

49. Oryshchenko, A.S.; Kuzmin, Y.L. Development of Electrochemical Cathodic Protection against Corrosion of Ships, Vessels, and Offshore Structures. Inorg. Mater. Appl. Res. 2015, 6, 612-625. [CrossRef]

50. Chernyi, S.G.; Erofeev, P.; Novak, B.; Emelianov, V. Investigation of the Mechanical and Electromechanical Starting Characteristics of an Asynchronous Electric Drive of a Two-Piston Marine Compressor. J. Mar. Sci. Eng. 2021, 9, 207. [CrossRef] 